\title{
Biofilm Formation by Staphylococcus aureus Isolated from Food Contact Surfaces in the Dairy Industry of Jalisco, Mexico
}

\author{
María-Guadalupe Avila-Novoa, Maricarmen Iñíguez-Moreno, \\ Oscar-Alberto Solís-Velázquez, Jean-Pierre González-Gómez, \\ Pedro-Javier Guerrero-Medina, and Melesio Gutiérrez-Lomelí \\ Laboratorio de Alimentos, Departamento de Ciencias Médicas y de la Vida, División de Desarrollo Biotecnológico, \\ Centro Universitario de la Ciénega, Universidad de Guadalajara, Av. Universidad 1115, Col. Lindavista, \\ 47820 Ocotlán, JAL, Mexico \\ Correspondence should be addressed to Melesio Gutiérrez-Lomelí; mele.gtz@gmail.com
}

Received 10 April 2018; Revised 6 June 2018; Accepted 12 July 2018; Published 19 August 2018

Academic Editor: Maria Rosaria Corbo

Copyright $\odot 2018$ María-Guadalupe Avila-Novoa et al. This is an open access article distributed under the Creative Commons Attribution License, which permits unrestricted use, distribution, and reproduction in any medium, provided the original work is properly cited.

Staphylococcus aureus is an important food-borne pathogen able to form biofilms. This pathogen is responsible for outbreaks of food-borne illnesses associated with the consumption of milk and dairy products. The aim of this study was to evaluate the biofilm-forming ability of $S$. aureus isolates, recovered from food contact surfaces in the dairy industry of Jalisco, Mexico. A total of $84 \mathrm{~S}$. aureus strains were evaluated. The isolates were characterized phenotypically by culture on Congo red agar plates. The ability of the strains to form biofilms was investigated in 96-well flat-bottomed microtiter polystyrene plates. Stainless-steel coupons were used as an experimental surface. Biofilm formation was observed, using epifluorescence microscopy and scanning electron microscopy. Detection of the icaADBC genes in S. aureus was performed by the PCR technique. A total of 52.3\% (44/84) of the $S$. aureus strains contained the icaADBC gene that synthesizes polysaccharide intercellular adhesion (PIA) molecules. On Congo red agar, $75 \%(63 / 84)$ of the $S$. aureus isolates were biofilm producers, $16.6 \%(14 / 84)$ were non-biofilm formers, and $8.3 \%$ (7/84) showed a noncharacteristic phenotype. The biofilm production of the S. aureus strains SA-4E, SA-9, SA-13, and SA-19 on stainless-steel coupons was investigated at $25^{\circ} \mathrm{C}$ for 8 days, and the detected cell population density was approximately $7.15-7.82$ $\log \mathrm{CFU} \mathrm{cm} \mathrm{cm}^{-2}$. In addition to the ability of biofilm production, it is important to highlight that these strains are potential enterotoxin producers as se genes have been previously detected in their genomes. A part of the ability of biofilm production and the determination of the presence of virulence determinants in the genome of $S$. aureus can contribute to the pathogenicity of strains. Therefore, vigilant food safety practices need to be implemented in the dairy industries regarding FCS to prevent foodborne infections and intoxications due to $S$. aureus contamination.

\section{Introduction}

In the food industry, biofilms increase bacterial resistance to environmental stresses including cleaning, disinfection, and inhibition, enabling these microorganisms to persist on surfaces and processing equipment, compared to planktonic cells [1-3]. Formation of biofilms can occur on all types of surfaces of technological systems in the dairy industry. The detection of biofilms in the food industry can be related to the presence of pathogenic microorganisms in the industrial settings.

Staphylococcus aureus is a food-borne pathogen that can cause staphylococcal food poisoning. In the USA, staphylococcal food poisoning is estimated to account for 241,188 illnesses, 1,064 hospitalizations, and six deaths, annually [4]. S. aureus can adhere to and develop biofilms on food contact surfaces, thereby affecting the quality and safety of food products $[5,6]$. The extracellular matrix of S. aureus biofilms is usually composed of exopolysaccharide (PIA/PNAG), but the proteinaceous and extracellular DNA matrix can also be present in staphylococcal biofilms [7]. Depending on the environment in which the biofilm was developed, the biofilm matrix can also contain blood components or noncellular materials such as mineral crystals, corrosion particles, and clay or silt particles [8]. PIA 
is linked to the irreversible attachment phase [9]. The formation of biofilm of Staphylococcus aureus is not only mediated by the PIA-dependent biofilm formation, but it can exist in PIA-independent biofilm. In the PIAindependent biofilm, despite the importance of the ica gene locus in biofilm development, biofilms can occur in an ica-independent fashion where biofilm-associated protein (Bap) and Bap-related proteins of $S$. aureus can confer biofilm development independently or PIA production through cell-to-cell aggregation and are characterized by their high molecular weight, presence of the bacterial surface, role as a virulence factor, and occasional containment in mobile elements $[10,11]$.

The main adhesion genes of $S$. aureus that are involved in cellular aggregation and bacterial accumulation within the biofilm are $b a p, b b p, c l f A, c l f B, c n a, e b p S, f i b, f n b A, f n b B$, eno, $i c a A D$, icaBC, sas $G$, sasC, and pls [12].

The aim of this study was to evaluate the biofilm-forming ability of $S$. aureus isolates, recovered from food contact surfaces in the dairy industry of Jalisco, Mexico.

\section{Materials and Methods}

2.1. S. aureus Isolates. S. aureus (SA1-SA84) strains were isolated from food contact surfaces (FCS) of six dairy industries in the Mexican state of Jalisco [13]. The $S$. aureus strains were identified by the methods described in the Bacteriological Analytical Manual (Gram staining, the coagulase and Voges-Proskauer tests, tests for catalase and thermostable nuclease, and glucose and mannitol utilization test), and finally, PCR was used for confirmation (PCR amplification of genes encoding for $23 \mathrm{~S}$ ribosomal RNA (rRNA) and thermonuclease (nuc)) [13]. The strains were cultivated in tryptic soy broth (TSB; Becton Dickinson Diagnostic Systems) for $24 \mathrm{~h}$ at $37^{\circ} \mathrm{C}$. All strains were subcultured in TSB with $0.25 \%$ glucose $(\mathrm{w} / \mathrm{v})$ for $24 \mathrm{~h}$ at $37^{\circ} \mathrm{C}$ for the quantification of biofilm formation and in TSB with $0.5 \%$ glucose $(w / v)$ for $8 \mathrm{~d}$ at $25^{\circ} \mathrm{C}$ for biofilm formation on stainless steel. The $S$. aureus strain ATCC 25923, a strong biofilm former, was used as a positive control.

\subsection{Biofilm Formation Assays}

2.2.1. Phenotype Analysis of Biofilm Production. The isolates were characterized phenotypically by culture on Congo red agar (CRA) plates, as described by Arciola et al. [14]. Briefly, agar plates were prepared by adding $0.8 \mathrm{~g}$ Congo red (Sigma-Aldrich) and $36 \mathrm{~g}$ saccharose (Sigma-Aldrich) to $1 \mathrm{~L}$ blood agar (Becton Dickinson Diagnostic Systems), followed by incubation at $37^{\circ} \mathrm{C}$ for 24 and $48 \mathrm{~h}$. The macroscopic characteristics of the $S$. aureus isolates in the CRA were observed. Crusty black colonies, with a dry filamentous appearance, were recorded as biofilm producers, smooth pink colonies as nonproducers, and intermediate colony morphology (pink with dark centers resembling bull's eyes), as potential biofilm producers [15].
2.2.2. Quantification of Biofilm Formation. The ability of the strains to form biofilms was investigated in 96-well flatbottomed microtiter polystyrene plates [16]. For each strain, three wells of the microtiter plate were filled with $200 \mu \mathrm{L}$ bacterial suspension in TSB with $0.25 \%$ glucose (w/v) (TSB $+0.25 \% \mathrm{G})$. Then, the plates were incubated at $37^{\circ} \mathrm{C}$ for $24 \mathrm{~h}$. Wells filled with the broth medium (TSB $+0.25 \% \mathrm{G})$ were used as negative controls, and S. aureus ATCC 25923 was used as the positive control. Next, the content of each well was aspirated and washed three times with phosphatebuffered saline (PBS; $7 \mathrm{mM} \mathrm{Na} \mathrm{HPO}_{4}, 3 \mathrm{mM} \mathrm{NaH} \mathrm{PO}_{4}$, and $130 \mathrm{mM} \mathrm{NaCl}, \mathrm{pH} 7.4$ ) to remove the planktonic bacteria. The attached bacteria were fixed with $95 \%$ ethanol for $5 \mathrm{~min}$; then, the plates were emptied and left to dry. The plates were stained with $100 \mu \mathrm{L}$ of $1 \%$ (w/v) crystal violet solution per well for $5 \mathrm{~min}$. The excess stain was rinsed off with sterile distilled water, and the microtiter plates were airdried. The optical density of each well was measured at $570 \mathrm{~nm}\left(\mathrm{OD}_{570}\right)$, using the Multiskan FC (Thermo Fisher Scientific Inc., Madison, WI). Biofilm formation was interpreted as highly positive $\left(\mathrm{OD}_{570} \geq 1\right)$, low-grade positive $\left(0.1 \leq \mathrm{OD}_{570}<1\right)$, or negative $\left(\mathrm{OD}_{570}<0.1\right)$.

2.2.3. Detection of icaADBC Genes. Genomic DNA was extracted, using the protocol described by $\mathrm{Pu}$ et al. [17]. Detection of the icaADBC genes in S. aureus was performed, as stated by Diemond-Hernández et al. [18]. The amplifications were performed using the Thermal Cycler (TechNet; Bibby Scientific Ltd., UK). The initial step $\left(94^{\circ} \mathrm{C}\right.$ for $5 \mathrm{~min}$ ) was followed by 30 cycles with annealing at $60^{\circ} \mathrm{C}$ for $1 \mathrm{~min}$ (icaA), $59^{\circ} \mathrm{C}$ for $1 \mathrm{~min}($ icaB $), 42^{\circ} \mathrm{C}$ for $1 \mathrm{~min}\left(\right.$ icaC), or $59^{\circ} \mathrm{C}$ for $1 \mathrm{~min}(\mathrm{icaD})$ and a final step at $72^{\circ} \mathrm{C}$ for $7 \mathrm{~min}$ (Table 1 ). After amplification, the products were electrophoresed on a $2 \%$ agarose gel (ultrapure agarose; Invitrogen), containing $0.5 \mu \mathrm{g} / \mathrm{mL}$ ethidium bromide (Sigma-Aldrich), and visualized by transillumination under ultraviolet light. S. aureus ATCC 25923 was used as the positive control.

2.3. Conditions for Biofilm Formation. Stainless-steel (SS) coupons (AISI $316,0.8 \times 2.0 \times 0.1 \mathrm{~cm}$ ) were used as an experimental surface. The coupons were consecutively cleaned, according to the method described by Marques et al. [5]. For the biofilm formation, each SS coupon was individually introduced into glass test tubes $(20 \times 150 \mathrm{~mm})$ containing $10 \mathrm{~mL}$ of TSB with $0.5 \%$ glucose (TSB $+0.5 \% \mathrm{G})$. The monospecies biofilms were inoculated with $100 \mu \mathrm{L}$ of cultures incubated at $37^{\circ} \mathrm{C} / 24 \mathrm{~h}$ (containing approximately $10^{8} \mathrm{CFU} / \mathrm{mL}$ of the corresponding strains) (Table 2); after that, the biofilms were incubated at $25^{\circ} \mathrm{C}$ for $8 \mathrm{~d}$. Afterwards, cell viability was determined by the standard plate count technique on standard agar (Becton Dickinson Diagnostic Systems) with incubation at $37^{\circ} \mathrm{C}$ for $24 \mathrm{~h}$. Biofilm formation was observed, using epifluorescence microscopy and scanning electron microscopy (SEM). Three replicates were performed for each strain. S. aureus ATCC 25923 was used as the positive control. As a negative control, an SS coupon without inoculum was included in all assays. 
TABLE 1: Primers used for amplification of the adhesin genes of Staphylococcus aureus [18].

\begin{tabular}{llr}
\hline Primers & \multicolumn{1}{c}{ Sequences $\left(5^{\prime}-3^{\prime}\right)$} & Product sizes (base pairs) \\
\hline $\begin{array}{l}\text { icaA forward } i c a A \text { reverse } \\
\text { icaB forward }\end{array}$ & GAC CTC GAA GTC AAT AGA GGT & 814 \\
icaB reverse & CCC AGT ATA ACG TTG GAT ACC & 526 \\
\hline icaC forward & ATC GCT TAA AGC ACA CGA CGC & \multirow{2}{*}{ icaC reverse } \\
\hline icaD forward & TAT CGG CAT CTG GTG TGA CAG & 989 \\
icaD reverse & ATA AAC TTG AAT TAG TGT ATT & 371 \\
\hline
\end{tabular}

TABLE 2: Primers used for the RAPD-PCR method.

\begin{tabular}{lc}
\hline Primers & Sequences $\left(5^{\prime}-3^{\prime}\right)$ \\
\hline OPL5 & ACGCAGGCAC \\
RAPD5 & AACGCGCAAC \\
P1 & CCGCAGCCAA \\
P2 & AACGGGCAGA \\
\hline
\end{tabular}

2.3.1. Epifluorescence Microscopy. After the incubation at $25^{\circ} \mathrm{C}$ for $8 \mathrm{~d}$, the SS coupons were removed from the glass test tubes containing $10 \mathrm{~mL}$ of TSB with $0.5 \%$ glucose using sterile forces. Each coupon was washed with $1 \mathrm{~mL}$ PBS for 10 s to eliminate nonadhered cells. The coupons were stained with 5(6)-carboxyfluorescein diacetate (CFDA; $10 \mu \mathrm{g} / \mathrm{mL}$ ), rinsed with sterile distilled water, dried in a level II cabinet, and observed under a Nikon Eclipse E400 epifluorescent microscope, using $100 \times$ oil immersion lens and the filter BA $515 \mathrm{~B} 2 \mathrm{a}$ at $450-900 \mathrm{~nm}$. At least 18 fields were observed. Once inside the cell, the diacetate is hydrolyzed by intracellular nonspecific esterases, producing carboxyfluorescein (CF), which is retained by live cells with an intact plasma membrane $[19,20]$.

2.3.2. SEM. After the incubation at $25^{\circ} \mathrm{C}$ for $8 \mathrm{~d}$, the SS coupons were treated as indicated in Section 2.3.1. They were further dried and transferred to $2 \%$ glutaraldehyde at $4^{\circ} \mathrm{C}$ for $2 \mathrm{~h}$ to fix the sample [21, 22]. Next, the samples were dehydrated in serial dilutions of ethanol at 30, 50, 60, 70, 90, and $95 \%$ at $4^{\circ} \mathrm{C}$ for 10 min each. Furthermore, three transfers were performed in $100 \%$ ethanol for $10 \mathrm{~min}$ each. The samples were vacuum-dried and gold-coated for $30 \mathrm{~s}$. Biofilms were observed, using a TESCAN Mira3 LMU scanning electron microscope.

2.4. Genomic Fingerprinting of S. aureus Isolates. The differentiation of the $S$. aureus isolates with genotypic and phenotypic characteristics associated with biofilm formation (presence of ica $A D B C$ genes, in addition to the presence of virulence determinants in their genome) was performed by the RAPD-PCR method. Primers used for this purpose were OPL5, RAPD5, P1, and P2 (Table 2) according to the method previously described $[23,24]$. Strains of $S$. aureus ATCC 25923 and 51811 and Lactobacillus delbrueckii subsp. bulgaricus ATCC 11778 were included to enable the comparison of genetic variability. RAPD-PCR band patterns from each primer were scanned, and profile grouping (dendrogram) was performed with the PAST (PAleontological Statistics) version 3.20 software (University of Oslo, Noruega), using Jaccard's coefficient and the unweighted pair-group method with arithmetic averages (UPGMA) cluster analysis [25].

2.5. Statistical Analysis. Pearson's chi-squared test was employed at the $p<0.05$ significance level to compare differences between groups. Statistical analysis was performed with SPSS for the Windows software, version 11.0.

\section{Results}

A total of 84 S. aureus strains (SA1-SA84) were studied to estimate their potential to adhere to, and, subsequently, form biofilms on food contact surfaces. Biofilms were quantified regarding biomass accumulation, using the crystal violet staining method. The $\mathrm{OD}_{570}$ results showed that $90.4 \%$ $(76 / 84)$ of the strains (SA1 to SA76) isolated from the food contact surfaces were low-grade biofilm formers $\left(0.1 \leq \mathrm{OD}_{570}<1\right), 7.1 \%(6 / 84)$ were highly positive biofilm formers $\left(\mathrm{OD}_{570} \geq 1\right)$, and $2.3 \%(2 / 84)$ were biofilm negative $\left(\mathrm{OD}_{570}<0.1\right)$. On CRA, $75 \%(63 / 84)$ of the $S$. aureus isolates were biofilm producers, $16.6 \%$ (14/84) were non-biofilm producers, and $8.3 \%$ (7/84) exhibit a noncharacteristic phenotype (Figure 1). At least one intercellular adhesion gene was present in $76.1 \%(64 / 84)$ of the S. aureus isolates with low-grade biofilm formation (Table 3). Some of the genes of the $i c a A D B C$ locus were detected in most of the strains, with a positive correlation $(r=0.798, p>0.05)$ between the icaADBC genes and CRA.

Among 84 S. aureus strains, four S. aureus (SA-4E, SA-9, SA-13, and SA-19) were examined by epifluorescence and SEM. The four $S$. aureus strains were considered, according to the genotypic and phenotypic characteristics associated with biofilm formation (Table 4 ). In addition to the ability of biofilm production, it is important to highlight that these strains are potential enterotoxin producers as se genes have been previously detected in their genomes [13]. The genetic variability of these strains of $S$. aureus isolates was determined by RAPD-PCR genotyping using four different primers (Table 2). Strains were grouped into five main clusters (I-V) (Figure 2). Cluster I is composed of strains SA-13 and SA19. Cluster II includes the strain SA-9. Cluster III includes the strain SA-4E. Group IV comprises the strains of Staphylococcus aureus ATCC 25923 and 51811. And finally, cluster $\mathrm{V}$ comprises the strain of Lactobacillus delbrueckii subsp. bulgaricus ATCC 11778. The genetic 

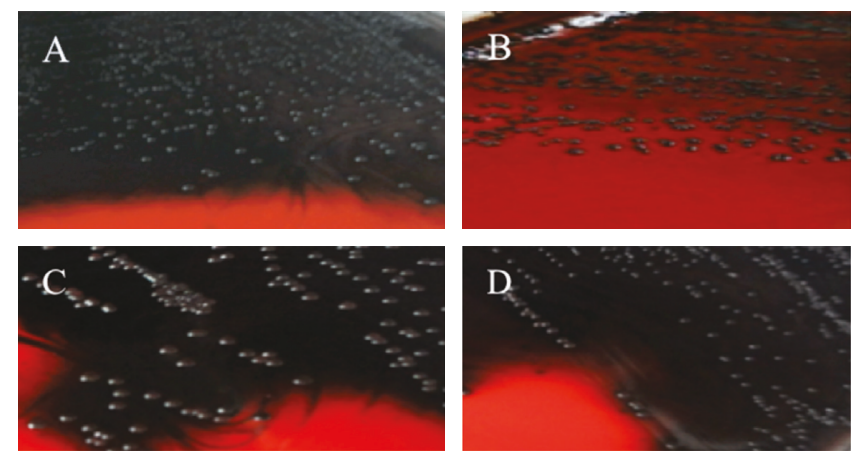

FIGURE 1: CRA plate test. Black colonies of the slime-producing S. aureus: (A) S. aureus 4E; (B) S. aureus 9; (C) S. aureus 13; (D) S. aureus 19.

TABLE 3: icaADBC genes in Staphylococcus aureus isolates from food contact surfaces.

\begin{tabular}{lcccccc}
\hline Strain & Number of isolates & $i c a B$ & $i c a D$ & $i c a A+i c a D$ & $i c a B+i c a C$ & $i c a A D B C$ \\
\hline S. aureus (SA1-SA84) & 64 & 1 & 2 & 16 & 1 & 44 \\
\hline
\end{tabular}

$\mathrm{SA}=$ S. aureus.

TABLE 4: Association between the biofilm phenotype on Congo red agar, slime production, adherence assay, and the presence of $i c a A D B C$ genes in Staphylococcus aureus.

\begin{tabular}{|c|c|c|c|c|c|c|c|c|}
\hline \multirow{2}{*}{ Bacterial strain } & \multirow{2}{*}{ Source } & \multicolumn{4}{|c|}{ Presence of $i c a A D B C$} & \multirow{2}{*}{ Adherence state } & \multirow{2}{*}{$\begin{array}{c}\text { Biofilm phenotype } \\
\text { on CRA }\end{array}$} & \multirow{2}{*}{$\begin{array}{c}\text { Slime } \\
\text { production }\end{array}$} \\
\hline & & $i c a A$ & $i c a B$ & $i c a C$ & $i c a D$ & & & \\
\hline $\begin{array}{l}\text { SA-4E } \\
\text { sec, sed, seg, sej, nuc* }\end{array}$ & FSC-stainless steel & + & + & + & + & Low-grade positive & Black & Figure $1(\mathrm{~A})$ \\
\hline $\begin{array}{l}\text { SA-9 } \\
\text { sec, sed, seh, sej, nuc* }\end{array}$ & FSC-stainless steel & + & + & + & + & Low-grade positive & Black & Figure $1(\mathrm{~B})$ \\
\hline $\begin{array}{l}\text { SA-13 } \\
\text { seb, sed, sei, nuc* }\end{array}$ & FSC-stainless steel & + & + & + & + & Highly positive & Black & Figure $1(\mathrm{C})$ \\
\hline $\begin{array}{l}\text { SA-19 } \\
\text { sea, sej, nuc* }\end{array}$ & FSC-stainless steel & + & + & + & + & Low-grade positive & Black & Figure $1(\mathrm{D})$ \\
\hline
\end{tabular}

${ }^{*}$ Virulence determinants in the genome of the strains of S. aureus [13].

variability of the strains of $S$. aureus was demonstrated by RAPD-PCR analysis.

The four $S$. aureus strains showed the ability to form single-species biofilms on SS coupons at $25^{\circ} \mathrm{C}$; cell adhesion was visualized during biofilm maturation by epifluorescence microscopy (Figure 3). With this technique, it is possible to observe the presence of metabolically active living cells, and the diacetate is hydrolyzed by intracellular nonspecific esterases, producing carboxyfluorescein $(\mathrm{CF})$ that indicates the integrity of the plasma membrane and esterase activity. Moreover, in the SEM microphotographs, the surface of microcolonies of the biofilm of the four $S$. aureus strains was visualized as well as probably the presence of the EPS (Figure 4). All isolates evaluated in this study had a concentration ranging from $7.15 \pm 0.15$ to $7.82 \pm 0.25 \log \mathrm{CFU}$ $\mathrm{cm}^{-2}$ on the SS coupons, and no significant differences $(p>0.05)$ were observed among them.

\section{Discussion}

Biofilms formed on food contact surfaces can lead to significant health problems. Biofilms reduce the effectiveness of sanitizers, cause economic losses to industries, and contaminate food and can increase the level of antimicrobial resistance [26]. Our results indicated that most of the examined $S$. aureus strains had at least one intercellular adhesion gene involved in the formation of PIA. Of note, 44 strains harbor the 4 genes of the icaADBC locus, which support their ability to produce biofilms. Most of the $S$. aureus strains formed the biofilm in an ica-dependent mechanism. This finding is consistent with results reported by Tang et al. [12], who detected icaAD and icaBC in $87.5 \%$ $(n=57)$ of $S$. aureus strains isolated from several sources (chicken, food samples, and goats). Gutiérrez et al. [27] also showed that $100 \%$ of $S$. aureus $(n=63)$ strains collected from various food contact surfaces in the dairy, meat, and seafood industries were positive for the icaA and icaD genes.

In the current study, most of the evaluated strains were $S$. aureus biofilm producers. Similar results were obtained by Szczuka et al. [9], who reported that, of 74 biofilm-positive strains, 56 carried the icaA (76\%) gene and produced slime on CRA. However, the variation between phenotypic and genotypic methods for detection of the biofilm produced by S. aureus has been reported, regarding CRA [28]. Congo red can directly interact with certain polysaccharides, forming 


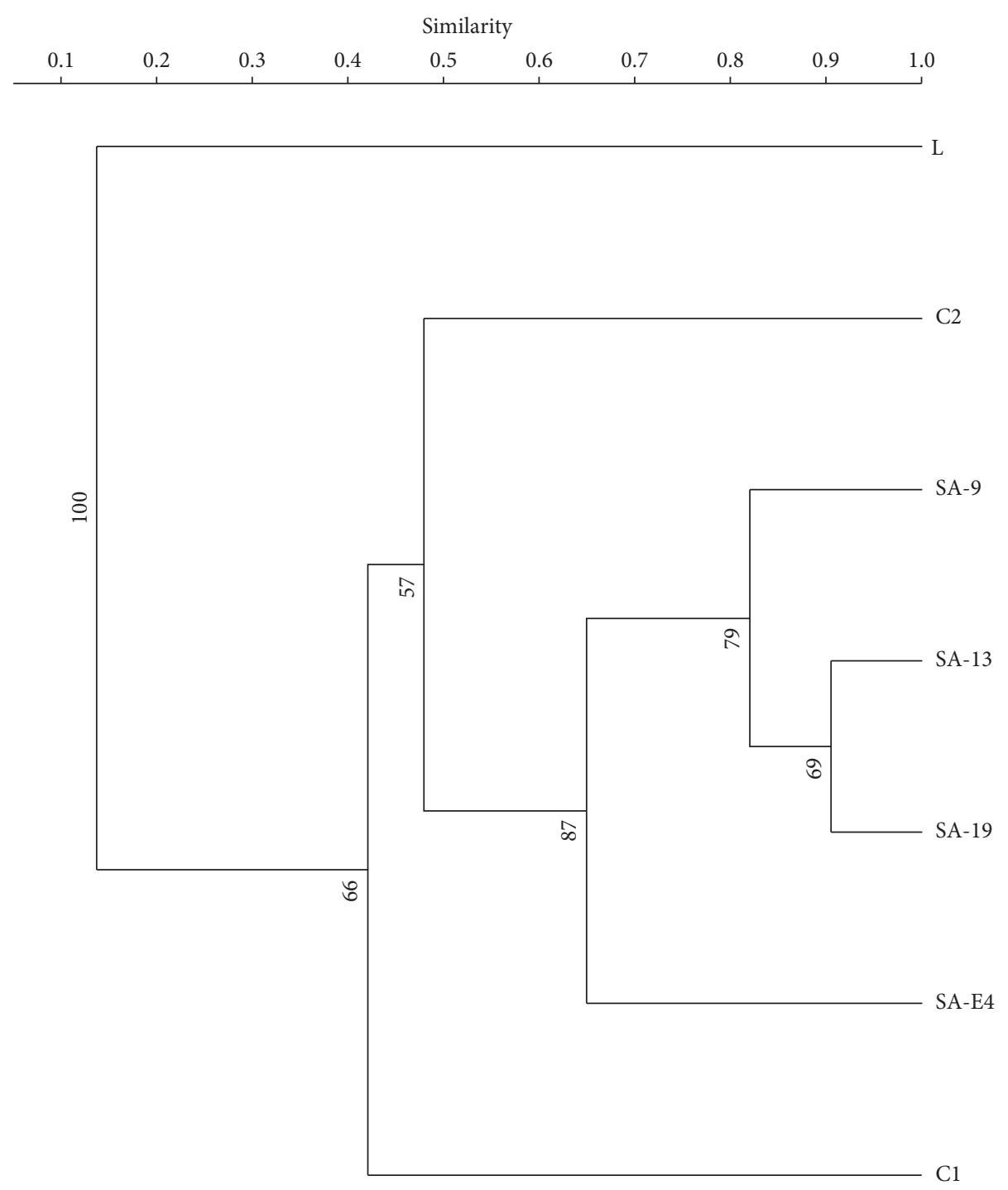

Figure 2: Dendrogram of isolated strains based on Jaccard's similarity coefficient. Strains: SA-4E, SA-9, SA-13, and SA-14 (Staphylococcus aureus isolated from food contact surfaces); C1 (Staphylococcus aureus ATCC 25923); C2 (Staphylococcus aureus ATCC 51811); L (Lactobacillus delbrueckii subsp. bulgaricus ATCC 11778).

colored pigments [29], and some metabolic reactions that form secondary products with the dye can influence the formation of dark colonies [14]. Nevertheless, Kim et al. [30] determined slime production under various environmental conditions ( $1 \%$ dextrose, $5 \% \mathrm{NaCl}$, and their combination) in four S. aureus strains (ATCC 12600, D8, D29, and C52), but the results did not indicate any influence of the tested conditions on slime production.

Consequently, the CRA technique could be used as the presumptive test for the formation of a biofilm. However, Arciola et al. [14] suggest that the phenotypic change may be caused by a deletion of the ica operon rather than an insertion event which inactivates the ica genes. The type of the food contact surface and diverse environmental factors, such as osmolarity, nutrient content, and temperature, and genetics, such as the presence of sarA, ica, and agr genes [31], may influence the development of a biofilm by $S$. aureus and, consequently, its persistence on contact surfaces within the food industry [32]. Moreover, the ica operon expression is strongly influenced by environmental factors, such as glucose, temperature, osmolarity, and growth under anaerobic conditions [33]. Li et al. [34] reported that, besides icaAD and $i c a B C$, other virulence regulators including $b a p$, sigB, and sar might be crucial biofilm-associated genes because these genes are expressed more often in biofilm-positive strains than in biofilm-negative strains.

Rode et al. [32] demonstrated that temperatures suboptimal for growth increased the biofilm formation in eleven $S$. aureus strains and the highest biofilm production occurred at 25,30 , and $46^{\circ} \mathrm{C}$, whereas, in general, biofilm formation was low at $42^{\circ} \mathrm{C}$. Da Silva Meira et al. [22] evaluated the biofilm formation of three food industry-associated $S$. aureus isolates on SS and polypropylene surfaces, incubated in a vegetablebased medium at two temperatures $\left(7\right.$ and $\left.28^{\circ} \mathrm{C} / 15 \mathrm{~d}\right)$, deducing that the biofilm development was favored at $28^{\circ} \mathrm{C}$, without significant differences between the type of surface. 

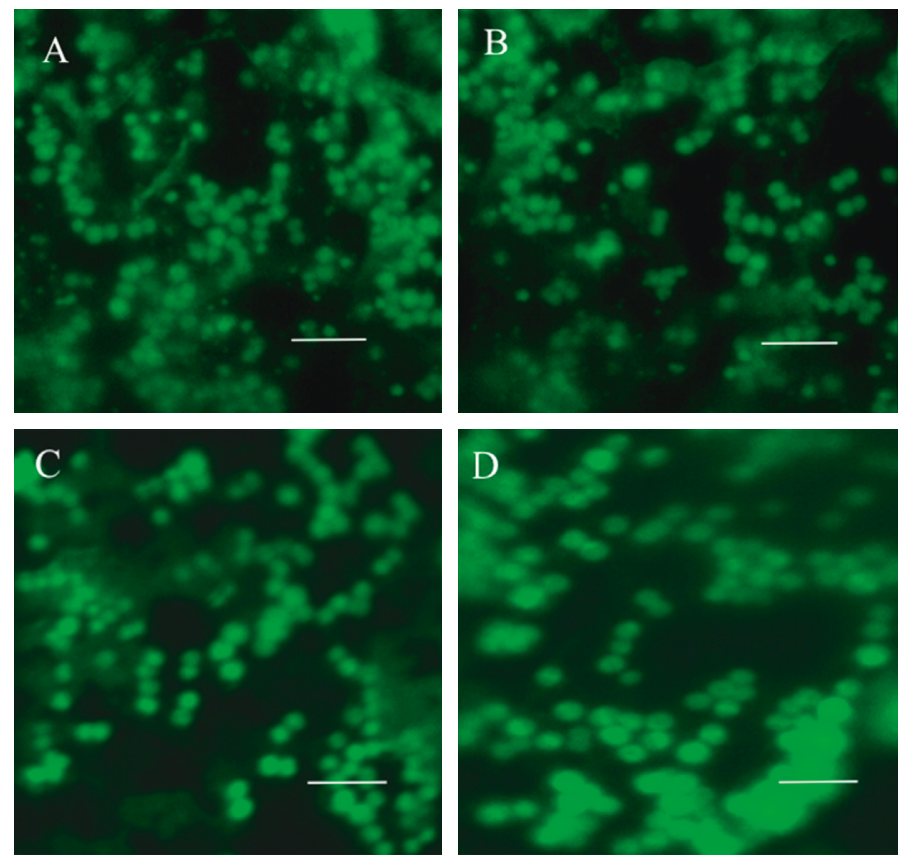

FIGURE 3: Epifluorescence photomicrograph of biofilms of Staphylococcus aureus isolates from food contact surfaces. Biofilms were developed on SS by 8 days of incubation in TSB with $0.5 \%$ glucose at $25^{\circ} \mathrm{C}$ : (A) S. aureus $4 \mathrm{E}$; (B) S. aureus 9 ; (C) S. aureus 13 ; (D) S. aureus 19. The white bar scale indicates $10 \mu \mathrm{m}$.
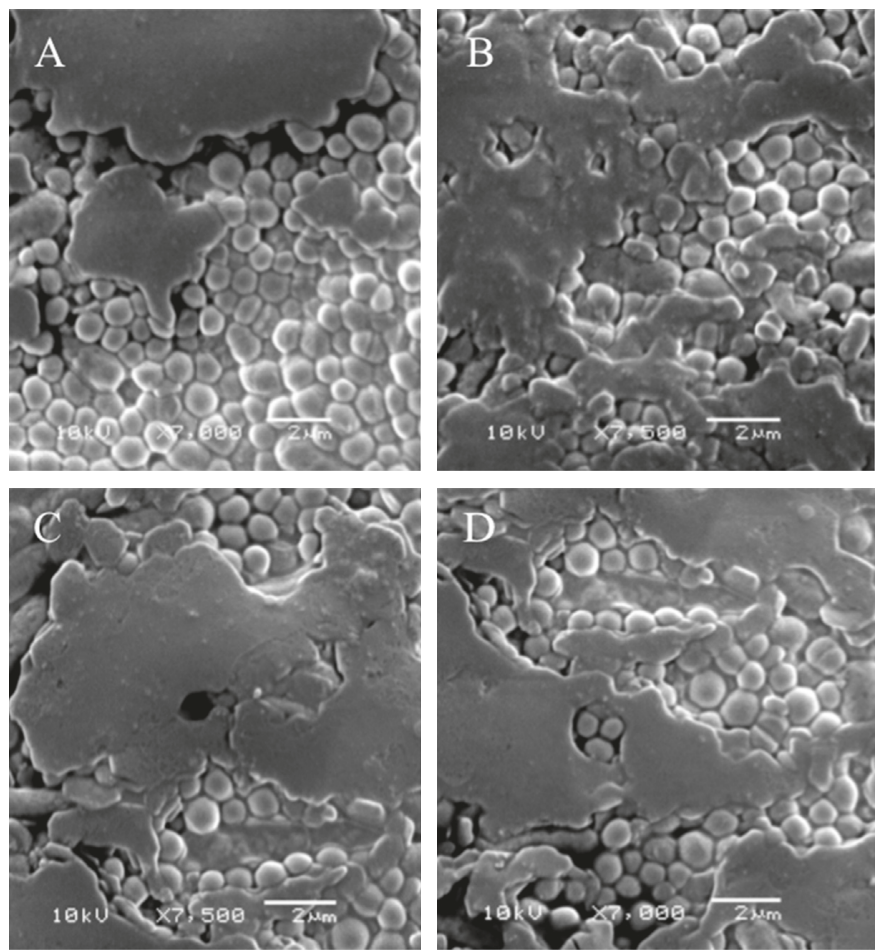

FIGURE 4: Scanning electron photomicrograph of biofilms of Staphylococcus aureus isolates from food contact surfaces. Biofilms were developed on SS by 8 days of incubation in TSB with $0.5 \%$ glucose at $25^{\circ} \mathrm{C}$ : (A) S. aureus $4 \mathrm{E}$; (B) S. aureus 9; (C) S. aureus 13 ; (D) S. aureus 19. Bar $=2 \mu \mathrm{m}$. 
Bae et al. [35] found that populations of five food-borne pathogens including $S$. aureus formed biofilms with 8.8-9.3 and 9.4-10.3 $\log \mathrm{CFU} /$ coupon on SS and polypropylene surfaces, respectively. Consequently, these isolates of $S$. aureus (SA-4E, SA-9, SA-13, and SA-19) have the ability to form biofilms on food contact surfaces.

\section{Conclusion}

In conclusion, this study showed the biofilm-forming ability of $S$. aureus, isolated from food contact surfaces in the dairy industry. Biofilm formation can cause public health problems and economic losses, associated with food contamination by the pathogen and equipment damage, by favoring equipment corrosion or resistance to hygiene treatments of food contact surfaces.

\section{Data Availability}

The data used to support the findings of this study are available from the corresponding author upon request.

\section{Conflicts of Interest}

The authors declare no conflicts of interest.

\section{References}

[1] M. Kostaki, N. Chorianopoulos, E. Braxou, G. J. Nychas, and E. Giaouris, "Differential biofilm formation and chemical disinfection resistance of sessile cells of Listeria monocytogenes strains under monospecies and dual-species (with Salmonella enterica) conditions," Applied and Environmental Microbiology, vol. 78, no. 8, pp. 2586-2595, 2012.

[2] K. Laird, D. Armitage, and C. Phillips, "Reduction of surface contamination and biofilms of Enterococcus spp. and Staphylococcus aureus using a citrus-based vapour," Journal of Hospital Infection, vol. 80, no. 1, pp. 61-66, 2012.

[3] A. Bridier, P. S. Vizuete, M. Guilbau, J. C. Piard, M. Naitali, and R. Briandet, "Biofilm-associated persistence of foodborne pathogens," Food Microbiology, vol. 45, pp. 167-178, 2015.

[4] E. Scallan, R. M. Hoekstra, F. J. Angulo et al., "Foodborne illness acquired in the United States-major pathogens," Emerging Infectious Diseases, vol. 17, no. 1, pp. 7-15, 2011.

[5] S. C. Marques, J. G. Silva-Rezende, L. P. de Freitas-Alves et al., "Formation of biofilms by Staphylococcus aureus on stainless steel and glass surfaces and its resistance to some selected chemical sanitiziers," Brazilian Journal of Microbiology, vol. 38, no. 3, pp. 538-543, 2007.

[6] S. Srey, I. J. Jahid, and S. D. Ha, "Biofilm formation in food industries: a food safety concern," Food Control, vol. 31, no. 2, pp. 572-585, 2013.

[7] B. R. Boles, M. Thoendel, A. J. Roth, and A. R. Horswill, "Identification of genes involved in polysaccharide-independent Staphylococcus aureus biofilm formation," PLoS One, vol. 5, no. 4, Article ID e10146, 2010.

[8] R. M. Donlan, "Biofilms: microbial life on surfaces," Emerging Infectious Diseases, vol. 8, no. 9, pp. 881-890, 2002.

[9] E. Szczuka, K. Urbanska, M. Pietryka, and A. Kaznowski, "Biofilm density and detection of biofilm-producing genes in methicillin-resistant Staphylococcus aureus strains," Folia Microbiology, vol. 58, no. 1, pp. 47-52, 2013.
[10] I. Lasa and J. R. Penades, "Bap: a family of surface proteins involved in biofilm formation," Research inMicrobiology, vol. 157, no. 2, pp. 99-107, 2006.

[11] N. K. Archer, M. J. Mazaitis, J. W. Costerton, J. G. Leid, M. E. Powers, and M. E. Shirtliff, "Staphylococcus aureus biofilm properties, regulation and roles in human disease," Virulence, vol. 2, no. 5, pp. 445-459, 2011.

[12] J. Tang, J. Chen, H. Li, P. Zeng, and J. Li, "Characterization of adhesin genes, staphylococcal nuclease, hemolysis, and biofilm formation among Staphylococcus aureus strains isolated from different source," Foodborne Pathogens and Diseases, vol. 10, no. 9, pp. 757-763, 2013.

[13] M. G. Avila-Novoa, M. Iñiguez-Moreno, J. P. González-Gómez et al., "Detection of enterotoxin genes of Staphylococcus aureus isolates from food contact surfaces in the dairy industry of Jalisco, Mexico," Biotecnia, vol. 20, no. 8, pp. 72-78, 2018.

[14] C. R. Arciola, L. Baldassarri, and L. Montanaro, "Presence of icaA and icaD genes and slime production in a collection of staphylococcal strains from catheter-associated infections," Journal of Clinical Microbiology, vol. 39, no. 6, pp. 2151-2156, 2001.

[15] C. R. Arciola, D. Campoccia, S. Gamberini, L. Baldassarri, and L. Montanaro, "Prevalence of $c n a, f n b A$ and $f n b B$ adhesin genes among Staphylococcus aureus isolates from orthopedic infections associated to different types of implant," FEMS Microbiology Letters, vol. 246, no. 1, pp. 81-86, 2005.

[16] B. Kouidhi, T. Zmantar, H. Hentati, and A. Bakhrouf, "Cell surface hydrophobicity, biofilm formation, adhesives properties and molecular detection of adhesins genes in Staphylococcus aureus," Microbial Pathology, vol. 49, no. 1-2, pp. 14-22, 2010.

[17] S. Pu, F. Wang, and B. Ge, "Characterization of toxin genes and antimicrobial susceptibility of Staphylococcus aureus isolates from Louisiana retail meats," Foodborne Pathogens and Diseases, vol. 8, no. 2, pp. 299-306, 2011.

[18] B. Diemond-Hernández, F. Sólorzano-Santos, B. LeañosMiranda, L. Peregrino-Bejarano, and G. Miranda-Novales, "Production of icaADBC-encoded polysaccharide intercellular adhesin and therapeutic failure in pediatric patients with staphylococcal device-related infections," BMC Infectious Diseases, vol. 10, no. 68, pp. 1-6, 2010.

[19] E. Gorokhova, L. Mattsson, and A. M. Sundstrom, "A comparison of TO-PRO-1 iodide and 5-CFDA-AM staining methods for assessing viability of planktonic algae with epifluorescence microscopy," Journal of Microbioligical Methods, vol. 89, no. 3, pp. 216-221, 2012.

[20] Y. Pan and L. Kaatz, "Use of image-based flow cytometry I bacterial viability analysis using fluorescent probes," Current Protocols in Microbiology, vol. 27, no. 1, pp. 1-11, 2012.

[21] M. Alhede, K. Qvortrup, R. Liebrechts, N. Hoiby, M. Givskov, and T. Bjarnsholt, "Combination of microscopic techniques reveals a comprehensive visual impression of biofilm structure and composition," FEMS Inmmunology and Medical Microbiology, vol. 65, no. 2, pp. 335-342, 2012.

[22] Q. G. Da Silva Meira, I. D. M. Barbosa, A. A. Athayde, J. P. Siqueira-Júnior, and E. L. Souza, "Influence of temperature and surface kind on biofilm formation by Staphylococcus aureus from food-contact surfaces and sensitivity to sanitizers," Food Control, vol. 25, no. 2, pp. 469-475, 2012.

[23] D. Gutiérrez, A. M. Martín-Platero, A. Rodríguez, M. Martínez-Bueno, P. García, and B. Martínez, "Typing of bacteriophages by randomly amplified polymorphic DNA (RAPD-PCR) to assess genetic variability," FEMS Microbiology Letters, vol. 322, no. 1, pp. 90-97, 2011. 
[24] T. B. Salgado-Ruiz, A. Rodríguez, D. Gutiérrez et al., "Molecular characterization and antimicrobial susceptibility of Staphylococcus aureus from small-scale dairy systems in the highlands of Central México," Dairy Science and Technology, vol. 95, no. 2, pp. 181-196, 2015.

[25] M. J. Struelens, "Consensus guidelines for appropriate use and evaluation of microbial epidemiologic typing systems," Clinical Microbiology and Infection, vol. 2, no. 1, pp. 2-11, 1996.

[26] T. F. Mah, "Biofilm-specific antibiotic resistance," Future Microbiology, vol. 7, no. 9, pp. 1061-1072, 2012.

[27] D. Gutiérrez, S. Delgado, D. Vázquez-Sánchez et al., "Incidence of Staphylococcus aureus and analysis of associated bacterial communities on food industry surfaces," Applied and Environmental Microbiology, vol. 78, no. 24, pp. 85478554, 2012.

[28] R. Yazdani, M. Oshaghi, A. Havayi et al., "Detection of icaAD gene and biofilm formation in Staphylococcus aureus isolates from wound infection," Iranian Journal of Public Health, vol. 35 , no. 2, pp. 25-28, 2006.

[29] A. Jain and A. Agarwal, "Biofilm production, a marker of pathogenic potential of colonizing and commensal staphylococci," Journal of Microbiological Methods, vol. 76, no. 1, pp. 88-92, 2009.

[30] B. R. Kim, Y. M. Bae, and S. Y. Lee, "Effect of environmental conditions on biofilm formation and related characteristic of S. aureus," Journal of Food Safety, vol. 36, no. 3, pp. 412-22, 2016.

[31] J. P. O'Gara, “ica and beyond: biofilm mechanisms and regulation in Staphylococcus epidermidis and Staphylococcus aureus," FEMS Microbiological Letters, vol. 270, no. 2, pp. 179-188, 2007.

[32] M. T. Rode, S. Langsrud, A. Holck, and T. Moretro, "Different patterns of biofilm formation in Staphylococcus aureus under food-related stress conditions," International Journal of Food Microbiology, vol. 116, no. 3, pp. 372-383, 2007.

[33] J. Kim, C. Kim, J. Hacker, W. Ziebuhr, B. K. Lee, and S. Cho, "Molecular characterization of regulatory genes associated with biofilm variation in a Staphylococcus aureus strain," Journal of Microbiology and Biotechnology, vol. 18, no. 1, pp. 28-34, 2008.

[34] L. Li, H. J. Yang, D. C. Liu et al., "Analysis of biofilm formation and associated gene detection in Staphylococcus isolates from bovine mastitis," African Journal of Biotechnology, vol. 11, no. 8, pp. 2113-2118, 2012.

[35] Y. M. Bae, S. G. Heu, and S. Y. Lee, "Inhibitory effect of dryheat treatment and chemical sanitizers against foodborne pathogens contaminated on the surfaces of materials," Journal of Korean Society of Food Science and Nutrition, vol. 38, no. 9, pp. 1265-1270, 2009. 


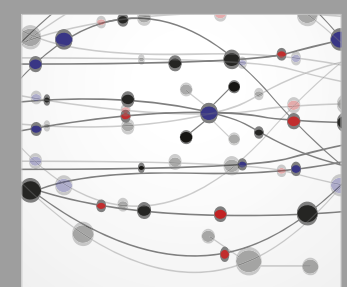

The Scientific World Journal
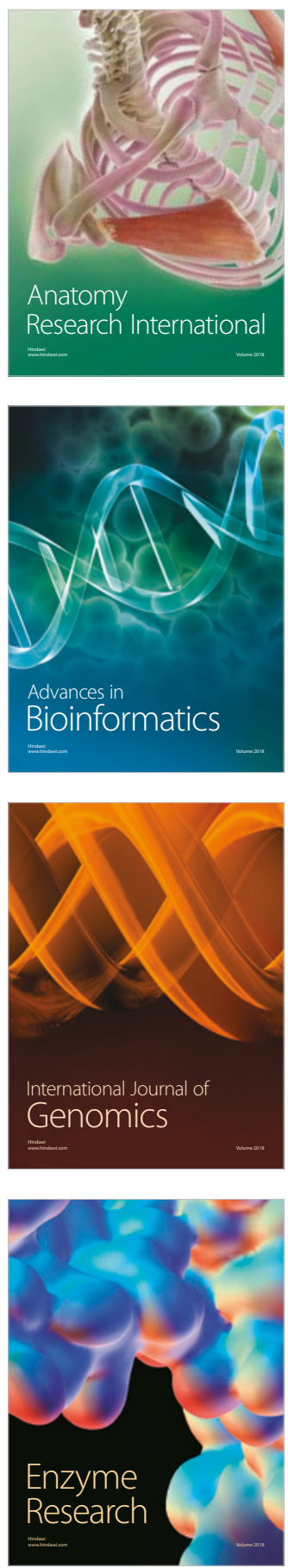
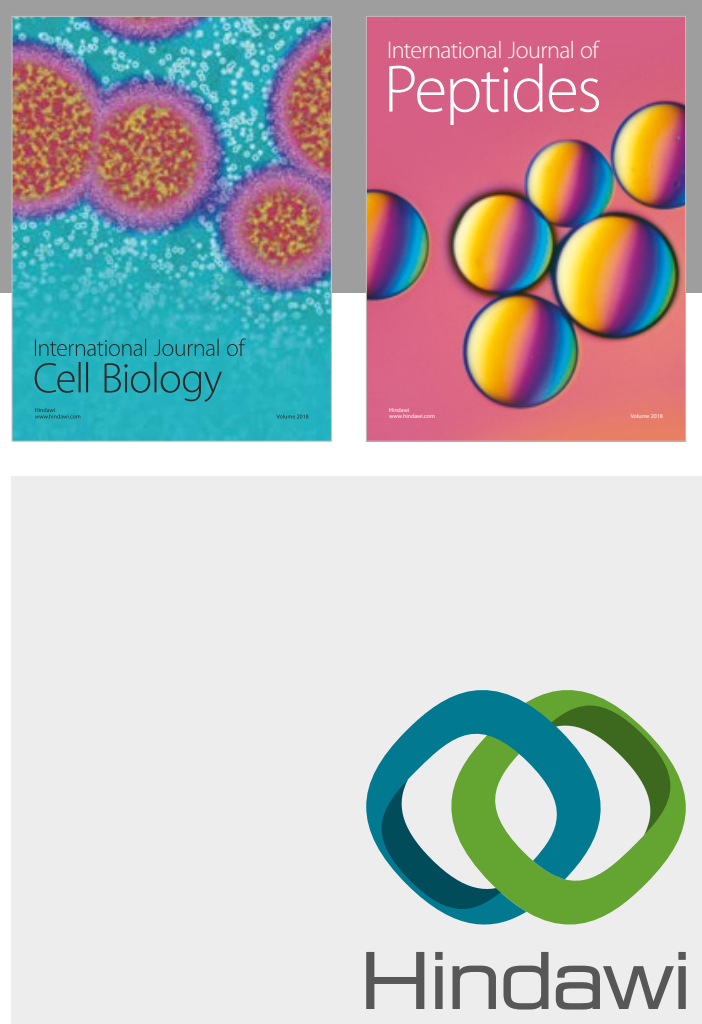

Submit your manuscripts at

www.hindawi.com
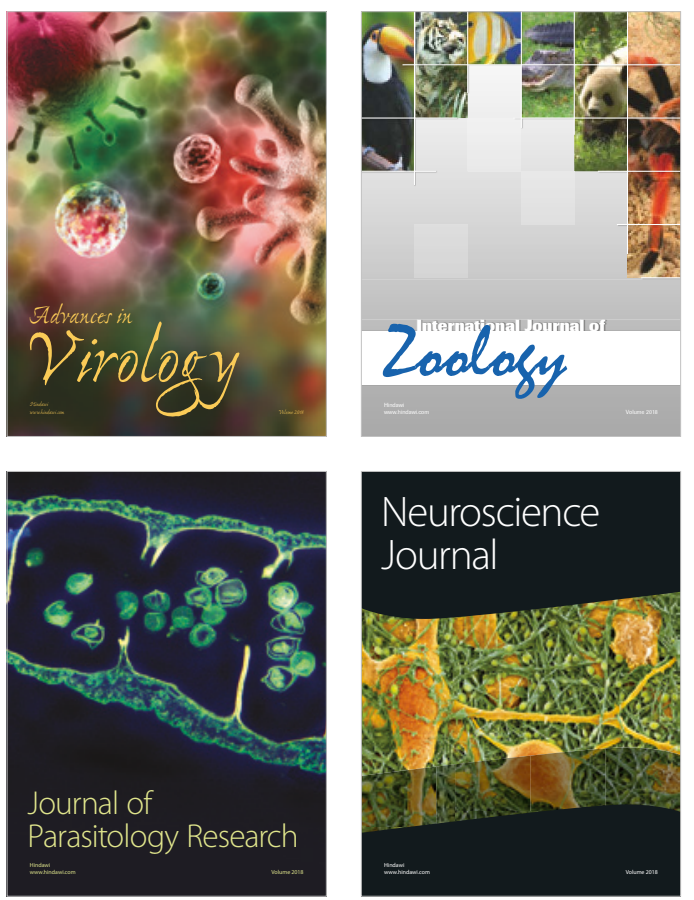
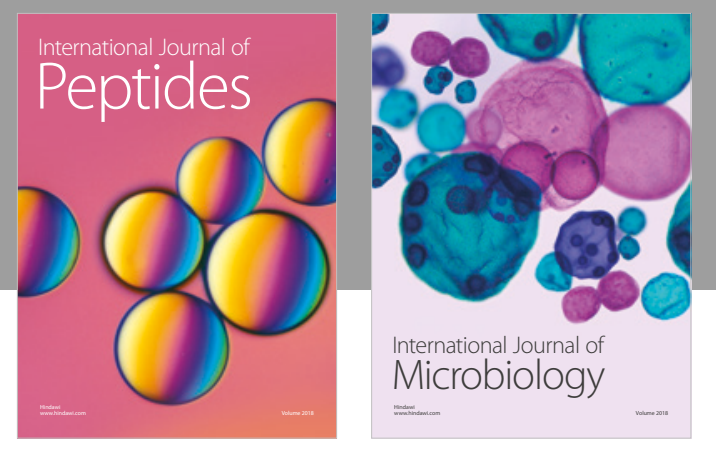

nternational Journal of Microbiology
Journal of
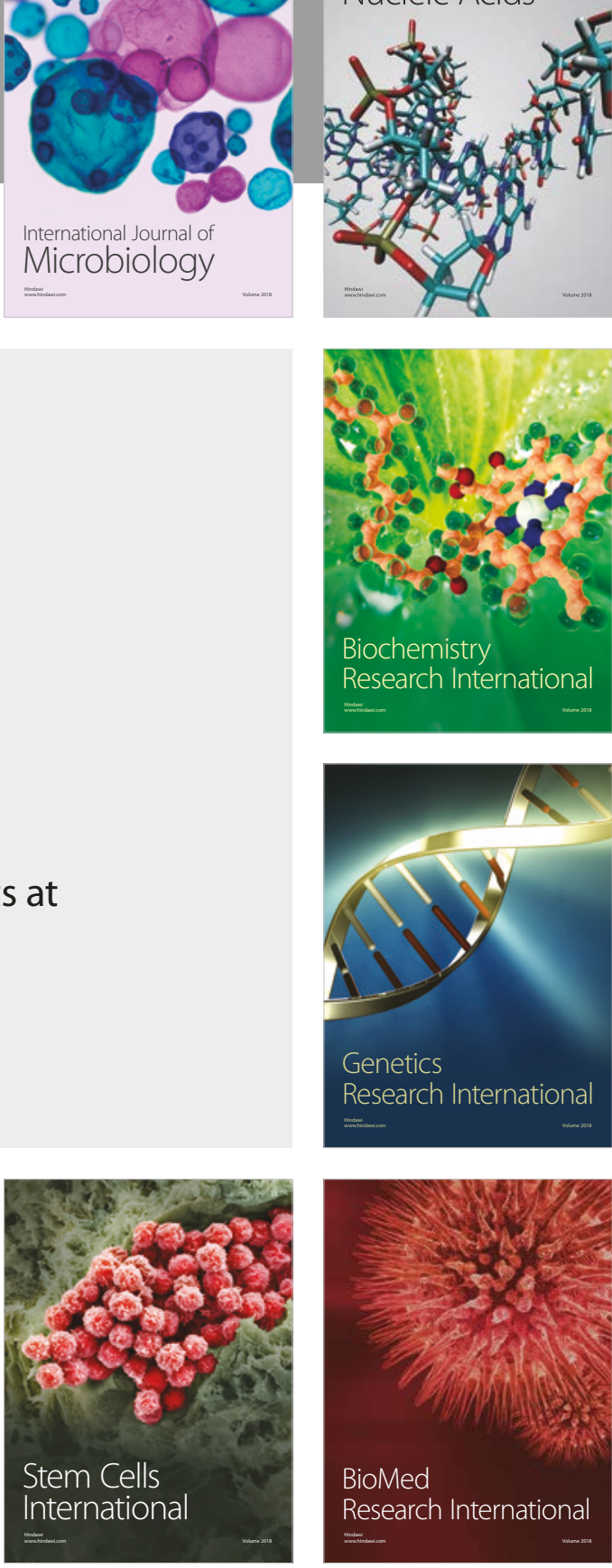
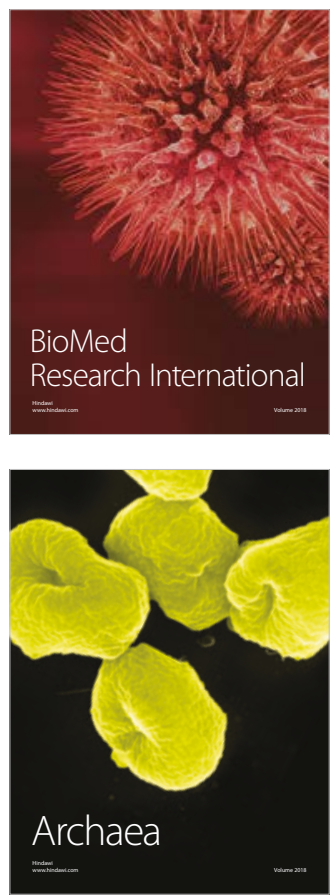